\title{
IMPROVEMENT OF THE SYSTEM OF ADMINISTRATION DRUGS CONTROL IN UKRAINE
}

\author{
УДОСКОНАЛЕННЯ СИСТЕМИ АДМІНІСТРУВАННЯ НАРКОТИКІВ В УКРАЇНІ
}

\author{
Ignatieva A.I., Candidate of Pedagogical Sciences, \\ Lecturer of the Department of Military Disciplines \\ Yaroslav Mudryi National Law University
}

Zverev S.M., Lieutenant-colonel, Deputy Head of the Military Law Institute for Logistics, Lecturer of the Department of Training Reserve Officers Yaroslav Mudryi National Law University The article deals with the the issue of administrative regulation of drug control administration is regulated by more than 100 legal acts.
Administrative and legal regulation of drug control administration consists in acting with the help of legal norms and other legal means on
the behavior of individuals in order to streamline, protect and develop public relations. In the legal aspect, the administrative and legal regulation
of drug control administration is carried out using special legal means to streamline public relations, including their legal consolidation, protection,
control over their stability and restoration in case of violation. The drug situation in Ukraine depends on the effectiveness of administrative and legal regulation of drug control administration.

The regulatory legal acts governing the administration of drug control can be divided into three groups. The first group includes normative acts issued by the highest bodies of state power of Ukraine, which contain, as a rule, general norms. These include: the Constitution of Ukraine, international documents, laws, decrees and orders of the President of Ukraine, resolutions of the Verkhovna Rada of Ukraine, resolutions and orders of the Cabinet of Ministers of Ukraine, decisions of local administrations. The second group consists of acts of a departmental nature (the Ministry of Health of Ukraine, the Ministry of Internal Affairs of Ukraine, the State Drug Control Service of Ukraine, joint acts of various ministries), which more specifically regulate the administration of drug control, and the third group of norms - acts of local authorities.

The project envisages resolving issues related to the activation of the activities of drug policy subjects in the implementation of appropriate measures and adoption of legal acts on improving the system of control over the circulation of drugs, psychotropic substances and precursors, preventing their leakage into illicit circulation and, at the same time, ensuring the availability of narcotic drugs funds for patients, actualization of the fight against organized crime, corruption and drug business, further improvement of legislation in this field.

Key words: regulation, norms, powers, drug administration, regulations, regulations, efficiency, Ministry of Internal Affairs of Ukraine, drug surveillance department, decisions.

У статті розглянуто питання адміністративного регулювання адміністрування наркотиків, урегульованого понад сотнею нормативноправових актів. Адміністративно-правове регулювання управління нагляду за наркотиками полягає у дії за допомогою правових норм та інших правових засобів щодо поведінки осіб з метою упорядкування, захисту та розвитку суспільних відносин. У юридичному аспекті адміністративно-правове регулювання управління наркотичними засобами здійснюється за допомогою спеціальних правових засобів для впорядкування суспільних відносин, включаючи їх юридичне закріплення, захист, контроль за їх стабільністю та відновлення у разі порушення. Ситуація з наркотиками в Україні залежить від ефективності адміністративно-правового регулювання управління наркотиками.

Нормативно-правові акти, що регулюють діяльність за контролем над наркотиками, можна розділити на три групи. До першої групи належать нормативні акти, видані вищими органами державної влади України, які містять загальні норми. До них належать: Конституція України, міжнародні документи, закони, укази та розпорядження Президента України, постанови Верховної Ради України, постанови та розпорядження Кабінету Міністрів України, рішення місцевих адміністрацій. Другу групу складають акти відомчого характеру (Міністерства охорони здоров'я України, Міністерства внутрішніх справ України, Державної служби контролю за наркотиками України, спільні акти різних міністерств), які конкретніше регламентують управління нагляду за наркотиками, і третя група норм - акти місцевих органів влади.

Проектом передбачено вирішити питання, пов'язані з активізацією діяльності суб'єктів політики щодо наркоманії при здійсненні відповідних заходів і прийнятті нормативно-правових актів щодо вдосконалення системи контролю за обігом наркотиків, психотропних речовин і прекурсорів, запобігання їх витоку в незаконний обіг і водночас забезпечення доступності наркотичних засобів для пацієнтів, актуалізації боротьби з організованою злочинністю, корупцією та наркобізнесом, подальшого вдосконалення законодавства у цій галузі.

Ключові слова: регулювання, норми, повноваження, адміністрування наркотиків, нормативні акти, нормативно-правові акти, ефективність, Міністерство внутрішніх справ України, управління нагляду за наркотиками, рішення.

Problem statement in a general form. The legislation of Ukraine in the field of drug control administration is a coherent system of legal rules. It is known that the most important feature of the system is the structure. In order to understand the system of legislation in the field of drug control, it is necessary first of all to find out its hierarchy, which is formed on the basis of the legal force of current normative acts, and is mainly determined by the system of state authorities of Ukraine and management. Among the national legal sources of administrative and legal regulation of drug trafficking control in Ukraine are:

a) a regulatory act,

b) a regulatory agreement,

c) a legal custom,

d) a legal precedent (judicial and administrative) [2, p. 12].

These sources are characterized by classification into two groups, namely: a) national, b) international law.

The group of international legal sources of such regulation includes agreements (treaties) of different levels and legal force. The first among the national sources of legal regulation of the administration of drug control should be called regulatory acts. This group of legal sources is quite significant. All of them form the legal and regulatory framework on the basis of which administrative and legal regulation of the administration of drug control is carried out in Ukraine.

Analysis of a recent researches. Administrative scientists of Ukraine (V.B. Averyanov, I.P. Gshosnichenko, T.O. Kolomoets, V.K. Kolpakov, A.T. Komzyuk, O.V. Kuzmenko, D.M. Lukianets and others), have repeatedly made proposals to study the rulemaking experience of certain states.

Formulating the goals of the article. The purpose of our study is to analyse administrative and legal regulation of drug management and identify ways to improve their activities.

Presenting a main material. The beginning of control over the distribution of drugs through legal norms dates back to the turn of the XIX-XX centuries.

The first step in this direction was the convening of the Shanghai Opium Commission, which took place in 
Shanghai from February 5 to February 26, 1909 with the participation of representatives of China, Italy, the Netherlands, Persia, Portugal and Siam. At the meetings of the Opium Commission, issues related to the international trade in opium were mainly discussed, opinions were expressed about the need to regulate the trade in opium and its gradual restriction. It was the beginning of international control over the distribution of drugs.

The process of establishing international drug control has been going on for all of the current century, beginning with the first ever drug convention produced at the International Hague Opium Conference. Twelve countries took part in it: Russia, Portugal, Persia, Netherlands, Japan, Italy, England, France, China, USA, Germany, India. All participants of the conference made a commitment to adopt legislation aimed at controlling the production and distribution of raw opium, and to limit the number of objects through which the transportation of opium would be carried out. In addition, the conference participants for the first time pledged to take control over the production and trade of cocaine, morphine, heroin, medical opium, and their derivatives.

The ever-increasing worldwide anti-narcotic activity led to the adoption of the 1925 International Opium Convention and the creation of a Central Standing Committee on Opium. Six years later, in Geneva on June 13, 1931, the International Convention on the Limitation of the Production and Regulation of the Distribution of Narcotic Drugs was signed and entered into force in 1933. It, among other things, first attempts to assess the world's needs for drugs as drugs and objects of study. On June 28, 1936, the Convention for the Suppression of the Illicit Traffic in Hazardous Medicines was concluded in Geneva [4, p. 24].

All three conventions were adopted in Geneva thanks to the political efforts of the League of Nations. They had a positive impact - according to them: a) a system of statistical control of licenses for import and export of drugs was introduced; b) limited production of drugs to the extent that satisfies medical and scientific needs; c) the imposition of strict measures to punish persons involved in drug trafficking is justified $[5, \mathrm{p}$. 9]

With the creation of the United Nations (hereinafter referred to as "The United Nations"), following the Second World War, the powers and functions previously exercised by the League of Nations assumed the United Nations by the Protocol of 1946. Subsequent UN protocols (1948 and 1953) provided for international and national control over the circulation of not only herbal drugs, as in previous decades, but also of some addictive synthetic drugs. The right to export opium was now granted to a limited list of countries. The international drug control system, which was formed in the 1940-s and 1950-s in the light of the development of the world community, was in need of substantial rebuilding. It was dramatically upgraded in 1961, as a result of the adoption of the 1961 Uniform Drugs Convention. The Central Standing Committee on Opium and the Narcotics Control Board have merged into the now known International Committee on Narcotics Control (hereinafter referred to as the ICCN). Other organizational structures have been set up at the United Nation, but the highest authority in this area is the United Nations Economic and Social Council's Narcotics Commission (hereinafter referred to as the Commission).

Let us state, that international anti-narcotic legislation consists of the three main United Nation Conventions on Drug Control a) the Single Convention of 1961; b) the 1971 Convention; c) 1988 Convention Consider the basic provisions of the conventions in the field of drug control [3, p.11].

According to Art. 2 of the Single Convention of 1961 (New York, March 30,1961), control measures are subject to narcotic drugs, depending on the list on which they are included (List I, List II, List IIII or List IV). According to Art. The 1961 Convention provides for the possibility of modifying any of the above lists, in individual cases where either Party provides the Secretary-General with the relevant information. If determines, that a substance is not yet on one of the lists, it may be subject to abuse and cause similar harmful effects to drugs listed in List I or List II, or may be converted into a drug, it informs the Commission in its opinion, which may decide that this substance should be added to Schedule I or Schedule I [2, p. 9].

If finds, that any drug containing a substance, which is not capable of being misused and cannot cause harmful effects and that the drug contained in it cannot be easily removed, the Commission may add that preparation to Schedule III. If finds that any drug is included to Schedule I may be subject to abuse and may have adverse effects and that such ability is not offset by significant therapeutic benefits not possessed by other substances. The Commission may add this drug to Schedule IV. The decisions of the Commission shall be approved by the Council.

The United Nation drug conventions are of great practical importance, namely: a) they introduce worldwide administrative control over the circulation of a number of hazardous substances causing addiction; b) constitute a single basis for drug law in most countries; c) is an obstacle to the uncontrolled drug trade; d) serve as the legal basis for international cooperation between the police and customs; e) support a system for collecting data on the state of affairs relating to the drug situation; f) offer ways to exchange experiences on how the abuse of various intoxicants occurs, on health hazards, on new forms of abuse; and also, which is an obstacle to the efforts of some countries to legalize drugs as a means of enjoyment.

A key concept in understanding the mechanism of statelegal regulation is its content, which is the effect of the norms of the right to conduct of members of public relations, which are carried out in the interests of the whole society or a certain collective in order to subordinate the behavior of certain entities established in society law and order [1, p. 12]

Legal aspects:

In the field of legal regulation there are:

The Law of Ukraine "On Narcotic Drugs, Psychotropic Substances and Precursors";

the Law of Ukraine "On Measures to Combat and Misuse Drugs, Psychotropic Substances and Precursors"; Resolution of the Cabinet of Ministers of Ukraine № 146 of 03.02.1997 “On Approving the Procedure for Issuing Permits for the Right to Import Drugs, Psychotropic Substances and Precursors from the Territory of Ukraine or Transit through the Territory of Ukraine";

Resolution of the Cabinet of Ministers of Ukraine of May 13, 2013 № 333 "On Approval of the Procedure for the Acquisition, Transportation, Storage, Release, Use and Destruction of Drugs, Psychotropic Substances and Precursors in Health Care Facilities";

Decree № 735 of the Cabinet of Ministers of Ukraine of August 28, 2013 "On Approval of the State Drug Policy Strategy for the period up to 2020 ".

The project envisages resolving issues related to the activation of the activities of drug policy subjects in the implementation of appropriate measures and adoption of legal acts on improving the system of control over the circulation of drugs, psychotropic substances and precursors, preventing their leakage into illicit circulation and, at the same time, ensuring the availability of narcotic drugs funds for patients, actualization of the fight against organized crime, corruption and drug business, further improvement of legislation in this field.

The project also envisages the implementation of measures to reduce the harm from the effects of psychoactive substance abuse, address the issues of medico-social orientation, strengthen cooperation with the European Monitoring Center for Drugs and Drug Addiction and other foreign entities. 
The main drawback of state legal regulation in Ukraine in the modern period is the lack of planning in the formation of legislation. It is necessary to carry out: joint investigative actions; operational, preventive and search activities, including the use of controlled delivery, the establishment and strengthening of specialized units to combat drug trafficking, equipping them with modern detection and identification devices [6, p. 14].

Conclusions prospects for further research. According to our results, having examined regulatory of legal acts in Ukraine for 2015-2019 years, we decided that, the current stage is characterized by the adoption of a number of regulatory acts, mainly regional ones, which take into account the peculiarities of the problem of administration of drug control in a particular region. In addition, the problem of counteracting the illegal carriage of narcotic drugs was aggravated, which led to the need for enhanced inter-state cooperation.

As a result, it can be noted, first of all, that Ukraine has an urgent task to improve the legal framework in the field of health care, to bring it in accordance with the requirements of international legal acts, taking into account international legal standards, the fundamental principles defined in international legal human rights documents, world politics and trends, but adapting to the domestic traditions and political, economic and social realities of our lives.

1. Офріційний вісник України. 2003. № 24. Ст. 1131.

\section{REFERENCES}

2. Офріційний вісник України. 2003. № 35. Ст. 1893.

3. Конституція України : Закон України від 28 червня 1996 р. № 254к / 96-ВР / Верховна Рада України. 1996. № 30.

4. Сидоренко Т.В., Жуковина Л.С. Правові засади реформи охорони здоров'я: стан, проблеми, перспективи розвитку. Право України. 2015.

5. Харитонова І.О. До питання про класифікацію правовідносин. Науковий вісник Чернівецького університету. Вип. 125: «Правознавство». Чернівці, 2016. С. 13-16.

6. Юридична енциклопедія : у 6 т. / ред. кол. : Ю.С. Шемчушенко та ін. Київ : Укр. Енцикл, 2016. 1244 с. 